\title{
Impact of Insulin Resistance, Body Mass Index, Disease Duration, and Duration of Metformin Use on the Efficacy of Vildagliptin
}

\author{
Anja Schweizer · Sylvie Dejager · James E. Foley
}

To view enhanced content go to www.diabetestherapy-open.com

Received: May 3, 2012 / Published online: June 27, 2012

(C) The Author(s) 2012. This article is published with open access at Springerlink.com

\section{ABSTRACT}

Introduction: The optimal stage for dipeptidyl peptidase-4 (DPP-4) inhibitor therapy in the course of type 2 diabetes mellitus (T2DM) is still under discussion, with often a perception that treatment with these agents may be less beneficial with increasing disease progression, due to loss of beta-cell function, and with increasing insulin resistance (IR), where betacell function is less prominent. This work, therefore, aimed to assess the impact of such factors on the efficacy of the DPP-4 inhibitor, vildagliptin, in add-on therapy to metformin.

A. Schweizer $(\square)$

Novartis Pharma AG, Postfach, 4002 Basel,

Switzerland

e-mail: anja.schweizer@novartis.com

S. Dejager

Novartis Pharma S.A.S, Rueil-Malmaison, France

J. E. Foley

Novartis Pharmaceuticals Corporation, East

Hanover, New Jersey, USA

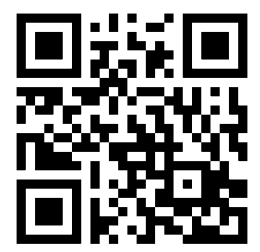

Enhanced content for this article is available on the journal web site: www.diabetestherapy-open.com
Methods: A pooled analysis of 24-week efficacy data of vildagliptin $50 \mathrm{mg}$ twice daily (b.i.d.) $(n=2,478)$ from four add-on to metformin studies was performed. Analyses for changes in hemoglobin $\mathrm{A}_{1 \mathrm{c}}\left(\mathrm{HbA}_{1 \mathrm{c}}\right)$ were stratified according to baseline IR stage (homeostasis model assessment [Homa IR] $<5, \geq 5$ ), body mass index (BMI) $\left(<27, \geq 27\right.$ to $\left.<30, \geq 30 \mathrm{~kg} / \mathrm{m}^{2}\right)$, T2DM duration ( 0 to $<1, \geq 1$ to $<5, \geq 5$ years), and duration of metformin use ( 0 to $<1, \geq 1$ to $<5, \geq 5$ years). Data from patients treated with sulfonylureas (SUs) $(n=2,010)$ in the pooled studies are provided as reference.

Results: Patients in the vildagliptin and SU groups had mean age, $\mathrm{HbA}_{1 \mathrm{c}}$, BMI, Homa IR, duration of T2DM and metformin use of 58 years, $7.7 \%, 32 \mathrm{~kg} / \mathrm{m}^{2}, 4.3,5.9$ years and 3.0 years, respectively. Reductions from baseline in $\mathrm{HbA}_{1 \mathrm{c}}$ with vildagliptin were very similar across Homa IR (mean 2.8 and 8.6), BMI (mean 24.9, 28.5 , and $35.3 \mathrm{~kg} / \mathrm{m}^{2}$ ), T2DM duration (mean 0.6, 2.9 , and 9.7 years), and duration of metformin use (mean $0.6,2.6$, and 7.9 years) categories, showing significant drops in $\mathrm{HbA}_{1 \mathrm{c}}$ of approximately $-0.7 \%$ (baseline $7.7 \%$ ). The results in patients receiving SUs were comparable to those seen in the vildagliptin group. 
Conclusion: Vildagliptin add-on therapy to metformin was efficacious independent of IR stage and BMI, as well as disease duration and duration of prior metformin use, indicating that, contrary to a not uncommon perception, more obese patients and patients with longstanding T2DM can benefit from treatment with the DPP-4 inhibitor, vildagliptin.

Keywords: Body mass index; Dipeptidyl peptidase-4; Disease duration; Efficacy; Hemoglobin $\mathrm{A}_{1 \mathrm{c}}$; Insulin resistance; Type 2 diabetes; Vildagliptin

\section{INTRODUCTION}

Type 2 diabetes mellitus (T2DM) is a progressive disease, with increasing insulin resistance (IR) (tied to obesity and/or adiposity) and deteriorating beta-cell function being key pathophysiologic defects in the development and worsening of hyperglycemia.

Based on the understanding of the pathogenesis of T2DM, several distinct pharmacological therapies have been developed. Within this armamentarium, dipeptidyl peptidase-4 (DPP-4) inhibitors are the most recent addition to the oral treatment options available in clinical practice for the treatment of T2DM.

The DPP-4 enzyme rapidly inactivates the incretin hormones, glucagon-like peptide-1 (GLP-1) and gastric inhibitory polypeptide (GIP) [1], which play a crucial role in glucose homeostasis [2, 3]. DPP-4 inhibitors bind to the catalytic site of DPP-4, resulting in prolonged inhibition of the enzyme, thus, raising levels of intact GLP-1 and GIP [4]. The resulting improvement in islet dysfunction is a key mechanism underlying the glucoselowering mechanism of DPP-4 inhibitors [4].
There is also a potential beta-cell preservation effect, as judged from rodent models, in which an increase in beta-cell mass through stimulation of neogenesis and proliferation, as well as an inhibition of apoptosis, has been seen with GLP-1/DPP-4 inhibitors [5, 6].

While DPP-4 inhibitor therapy has been studied in a variety of clinical study settings [7-10], the optimal stage for their use in the course of T2DM is still under debate. Based on the known effects on beta-cell function, there is frequently a perception that treatment with these agents may be less efficacious with increasing disease progression, due to loss of beta-cell function, and with increasing IR, where beta-cell function is proportionally less important.

The present paper, therefore, aimed to evaluate the impact of such factors (i.e., T2DM duration and duration of previous therapy, and IR and body mass index [BMI]) on the efficacy of the DPP-4 inhibitor, vildagliptin, using a pooled database of studies in add-on therapy to metformin. Vildagliptin is a DPP-4 inhibitor that has been extensively studied in a large clinical program, with proven efficacy and a well-established safety profile [8, 11-14]. The present paper reports the results of these new pooled subgroup analyses with vildagliptin.

\section{METHODS}

\section{Populations}

The efficacy analyses included all randomized, double-blind, controlled, parallel-group add-on to metformin studies with vildagliptin $50 \mathrm{mg}$ twice daily (b.i.d.) (the highest approved and most commonly used dose of the drug). A total of four studies were pooled (termed 'pooled add-on to metformin population'). 
The efficacy population comprised all patients who were included in the respective primary efficacy populations of the individual studies [15-18]. Data collected in the first 24 weeks of treatment from these studies were included in the analyses. Details of the study designs are summarized in Appendix Table 3 and the individual study publications [15-18].

\section{Assessments}

Hemoglobin $\mathrm{A}_{1 \mathrm{c}}\left(\mathrm{HbA}_{1 \mathrm{c}}\right)$ was measured regularly in all studies. The laboratory assessments were performed by central laboratories: Bioanalytical Research Corporation-EU (Ghent, Belgium), Diabetes Diagnostics Laboratory (Columbia, MO, US), and Covance (Geneva, Switzerland, Singapore, or Indianapolis, IN, US).

Homeostasis model assessment IR (Homa IR) was calculated based on the following formula: Homa $\mathrm{IR}=($ fasting insulin $[\mu \mathrm{U} / \mathrm{mL}]) \times($ fasting glucose $[\mathrm{mmol} / \mathrm{L}]) / 22.5$. Glomerular filtration rate (GFR) was estimated by the Modification of Diet in Renal Disease study method (MDRD) [19].

\section{Data Analysis}

The total number of patients, and demography and baseline characteristics were recorded.

Efficacy analyses were stratified according to baseline IR stage (Homa IR $<5$ and $\geq 5$ ), BMI $\left(<27, \geq 27\right.$ to $\left.<30, \geq 30 \mathrm{~kg} / \mathrm{m}^{2}\right)$, T2DM duration ( 0 to $<1, \geq 1$ to $<5, \geq 5$ years), and duration of metformin use ( 0 to $<1, \geq 1$ to $<5, \geq 5$ years). Mean changes from baseline in $\mathrm{HbA}_{1 \mathrm{c}}$ at the week 24 endpoint in the defined subgroups were analyzed using last observation carried forward (LOCF). Within-group comparisons (endpoint vs. baseline) were made using onesample $t$ test at a significance level of 0.05 .

Efficacy data are reported for vildagliptin $50 \mathrm{mg}$ b.i.d. $(n=2,478)$, with data from patients treated with a sulfonylurea (SU) in the pooled studies being provided as reference $(n=2,010)$. While the SU group had a comparable number of patients to the vildagliptin group, the two other comparator groups in the studies (placebo and thiazolidinedione [TZD]) comprised only $2.6 \%$ and $5.7 \%$, respectively, of patients in the pooled population; thus, not representing meaningful reference groups to be analyzed.

\section{Ethics and Good Clinical Practice}

All study participants provided written informed consent. All protocols were approved by the independent ethics committee/ institutional review board at each study site or country. All studies were conducted using good clinical practice and in accordance with the Declaration of Helsinki.

\section{RESULTS}

\section{Demography}

Table 1 summarizes the demographic and baseline characteristics of patients in the pooled add-on to metformin population. The population studied was representative of a broad spectrum of T2DM patients, with a mean age of 58 years, mean $\mathrm{HbA}_{1 \mathrm{c}}$ of $7.7 \%$, mean fasting blood glucose (FPG) of $9.6 \mathrm{mmol} / \mathrm{L}$, mean BMI of $32 \mathrm{~kg} / \mathrm{m}^{2}$, and mean Homa IR of 4.3 , respectively. The mean duration of diagnosed T2DM was 5.9 years, with a mean duration of metformin use of 3.0 years. Approximately 30\% of patients had renal impairment (mostly mild), $>65 \%$ had hypertension, and about 50\% had dyslipidemia. The majority of patients (>80\%) were Caucasian. The demographic and baseline characteristics were comparable across the vildagliptin group and the SU reference group. 
Table 1 Demography and baseline characteristics (pooled add-on to metformin population)

\begin{tabular}{|c|c|c|}
\hline $\begin{array}{l}\text { Mean } \pm \text { SD } \\
\text { or } n(\%)\end{array}$ & $\begin{array}{l}\text { Vilda } 50 \mathrm{mg} \\
\text { b.i.d. }+ \text { metformin }\end{array}$ & $S U+$ metformin \\
\hline $\bar{n}$ & 2,478 & 2,010 \\
\hline Age (years) & $57.5 \pm 9.4$ & $58.0 \pm 9.5$ \\
\hline$\geq 65$ & $638(25.7)$ & $595(29.6)$ \\
\hline \multicolumn{3}{|l|}{ Sex } \\
\hline Male & $1,347(54.4)$ & $1,070(53.2)$ \\
\hline Female & $1,131(45.6)$ & $940(46.8)$ \\
\hline \multicolumn{3}{|l|}{ Race } \\
\hline Caucasian & $2,089(84.3)$ & $1,691(84.1)$ \\
\hline Black & $43(1.7)$ & $25(1.2)$ \\
\hline Asian & $103(4.2)$ & $86(4.3)$ \\
\hline Hispanic/Latino & $227(9.2)$ & $190(9.5)$ \\
\hline All other & $16(0.6)$ & $18(0.9)$ \\
\hline$n$ & 2,477 & 2,010 \\
\hline $\mathrm{HbA}_{1 \mathrm{c}}(\%)$ & $7.7 \pm 1.0$ & $7.6 \pm 0.9$ \\
\hline$n$ & 2,475 & 2,009 \\
\hline FPG $(\mathrm{mmol} / \mathrm{L})$ & $9.7 \pm 2.5$ & $9.5 \pm 2.5$ \\
\hline$n$ & 2,472 & 2,003 \\
\hline BMI $\left(\mathrm{kg} / \mathrm{m}^{2}\right)$ & $31.9 \pm 5.3$ & $31.5 \pm 5.2$ \\
\hline$\leq 27$ & $465(18.8)$ & $421(20.9)$ \\
\hline$\leq 30$ & $1,022(41.2)$ & $878(43.7)$ \\
\hline$>30$ & $1,450(58.5)$ & $1,125(56.0)$ \\
\hline$>35$ & $651(26.3)$ & $468(23.3)$ \\
\hline Not recorded & $6(0.2)$ & $7(0.3)$ \\
\hline$n$ & 2,121 & 1,703 \\
\hline Homa IR & $4.4 \pm 4.2$ & $4.2 \pm 3.7$ \\
\hline$<5$ & $1,519(61.3)$ & $1,267(63.0)$ \\
\hline$\geq 5$ & $602(24.3)$ & $436(21.7)$ \\
\hline Not recorded & $357(14.4)$ & $307(15.3)$ \\
\hline$n$ & 2,478 & 2,010 \\
\hline $\begin{array}{l}\text { Duration of T2DM } \\
\text { (years) }\end{array}$ & $5.9 \pm 5.1$ & $6.0 \pm 5.1$ \\
\hline 0 to $<1$ & $237(9.6)$ & $202(10.0)$ \\
\hline$\geq 1$ to $<5$ & $1,079(43.5)$ & $850(42.3)$ \\
\hline$\geq 5$ & $1,162(46.9)$ & $958(47.7)$ \\
\hline$n$ & 2,477 & 2,010 \\
\hline $\begin{array}{l}\text { Duration of } \\
\text { metformin use } \\
\text { (years) }\end{array}$ & $3.0 \pm 3.0$ & $3.0 \pm 2.9$ \\
\hline 0 to $<1$ & $713(28.8)$ & $591(29.4)$ \\
\hline$\geq 1$ to $<5$ & $1,294(52.2)$ & $1,047(52.1)$ \\
\hline$\geq 5$ & $470(19.0)$ & $372(18.5)$ \\
\hline Not recorded & $1(0.0)$ & $0(0.0)$ \\
\hline
\end{tabular}

Table 1 continued

\begin{tabular}{lll}
\hline $\begin{array}{l}\text { Mean } \mathbf{\pm} \text { SD } \\
\text { or } \boldsymbol{n}(\%)\end{array}$ & $\begin{array}{l}\text { Vilda } 50 \text { mg } \\
\text { b.i.d. + metformin }\end{array}$ & SU + metformin \\
\hline$n$ & 2,478 & 2,010 \\
$\begin{array}{l}\text { Medical history } \\
\text { GFR }(\mathrm{MDRD})\end{array}$ & & \\
$\begin{array}{l}(\mathrm{mL} / \mathrm{min}) \\
\text { per }\left(1.73 \mathrm{~m}^{2}\right)\end{array}$ & & \\
$\quad$ Normal & $1,713(69.1)$ & $1,367(68.0)$ \\
$\quad$ Mild $(\geq 50, \leq 80)$ & $739(29.8)$ & $626(31.1)$ \\
$\quad$ Moderate & $23(0.9)$ & $17(0.8)$ \\
$\quad(\geq 30, \leq 50)$ & & $0(0.0)$ \\
$\quad$ Severe $(<30)$ & $2(0.1)$ & $0(0.0)$ \\
$\quad$ Not recorded & $1(0.0)$ & $1,375(68.4)$ \\
Hypertension & $1,586(64.0)$ & $992(49.4)$ \\
Dyslipidemia & $1,279(51.6)$ & \\
\hline
\end{tabular}

b.i.d. twice daily, $B M I$ body mass index, $F P G$ fasting plasma glucose, GFR glomerular filtration rate, $H b A_{l c}$ hemoglobin $\mathrm{A}_{1 c}$, Homa IR homeostasis model assessment insulin resistance, $M D R D$ Modification of Diet in Renal Disease, $S U$ sulfonylurea, $T 2 D M$ type 2 diabetes mellitus, Vilda vildagliptin

\section{Efficacy by Subgroups}

Table 2 displays mean changes from baseline to week 24 in $\mathrm{HbA}_{1 \mathrm{c}}$ with vildagliptin $50 \mathrm{mg}$ b.i.d. according to Homa IR, BMI, T2DM duration, and duration of metformin use in the pooled add-on to metformin population.

The influence of IR on the efficacy of vildagliptin was assessed by stratification according to two baseline Homa IR categories, Homa IR $<5 \quad($ mean $=2.8)$ and Homa IR $\geq 5$ (mean $=8.6$ ). In addition, three BMI categories were analyzed, BMI $<27 \mathrm{~kg} / \mathrm{m}^{2}$ (mean $=24.9 \mathrm{~kg} / \mathrm{m}^{2}$ ), $\geq 27$ to $<30 \mathrm{~kg} / \mathrm{m}^{2} \quad\left(\right.$ mean $\left.=28.5 \mathrm{~kg} / \mathrm{m}^{2}\right), \quad$ and $\geq 30 \mathrm{~kg} / \mathrm{m}^{2} \quad\left(\right.$ mean $\left.=35.3 \mathrm{~kg} / \mathrm{m}^{2}\right) . \quad \mathrm{HbA}_{1 \mathrm{c}}$ was reduced to a very similar extent independent of baseline Homa IR or BMI category. For example, $\mathrm{HbA}_{1 \mathrm{c}}( \pm \mathrm{SE})$ was reduced by $-0.67 \pm$ $0.04 \%$ (baseline $7.80 \pm 0.05 \%$ ), $-0.67 \pm 0.04 \%$ (baseline $7.74 \pm 0.04 \%$ ), and $-0.63 \pm 0.02 \%$ (baseline $7.72 \pm 0.03 \%$ ) in the BMI subgroups of $<27, \geq 27$ to $<30$, and $\geq 27 \mathrm{~kg} / \mathrm{m}^{2}$, respectively. 
Table 2 Efficacy $\left(\mathrm{HbA}_{1 \mathrm{c}}[\%]\right)$ by Homa IR, BMI, T2DM duration and duration of metformin use

\begin{tabular}{|c|c|c|c|c|}
\hline & \multicolumn{2}{|c|}{ Vilda $50 \mathrm{mg}$ b.i.d. + metformin } & \multicolumn{2}{|c|}{$S U+$ metformin } \\
\hline & $\overline{B L}$ & Mean $\Delta$ & $\overline{B L}$ & Mean $\Delta$ \\
\hline \multicolumn{5}{|l|}{ BL Homa IR } \\
\hline$n$ & 1,507 & & 1,237 & \\
\hline$<5($ mean $=2.8 / 2.7)$ & $7.63 \pm 0.02$ & $-0.65 \pm 0.02^{*}$ & $7.51 \pm 0.03$ & $-0.76 \pm 0.02^{*}$ \\
\hline$n$ & 598 & & 428 & \\
\hline$\geq 5($ mean $=8.6 / 8.3)$ & $8.07 \pm 0.05$ & $-0.68 \pm 0.04^{*}$ & $7.80 \pm 0.05$ & $-0.77 \pm 0.05^{*}$ \\
\hline \multicolumn{5}{|l|}{ BL BMI } \\
\hline$n$ & 444 & & 398 & \\
\hline$<27 \mathrm{~kg} / \mathrm{m}^{2}($ mean $=24.9 / 25.1)$ & $7.80 \pm 0.05$ & $-0.67 \pm 0.04^{*}$ & $7.66 \pm 0.05$ & $-0.80 \pm 0.04^{*}$ \\
\hline$n$ & 556 & & 453 & \\
\hline$\geq 27$ to $<30 \mathrm{~kg} / \mathrm{m}^{2}($ mean $=28.5 / 28.4)$ & $7.74 \pm 0.04$ & $-0.67 \pm 0.04^{*}$ & $7.59 \pm 0.04$ & $-0.79 \pm 0.04^{*}$ \\
\hline$n$ & 1,446 & & 1,106 & \\
\hline$\geq 30 \mathrm{~kg} / \mathrm{m}^{2}($ mean $=35.3 / 35.1)$ & $7.72 \pm 0.03$ & $-0.63 \pm 0.02^{*}$ & $7.58 \pm 0.03$ & $-0.73 \pm 0.03^{*}$ \\
\hline \multicolumn{5}{|l|}{$\mathrm{BL}$ T2DM duration } \\
\hline$n$ & 236 & & 198 & \\
\hline 0 to $<1$ year $($ mean $=0.6 / 0.6)$ & $7.47 \pm 0.06$ & $-0.64 \pm 0.05^{*}$ & $7.32 \pm 0.06$ & $-0.73 \pm 0.06^{*}$ \\
\hline$n$ & 1,061 & & 829 & \\
\hline$\geq 1$ to $<5$ years $($ mean $=2.9 / 2.9)$ & $7.65 \pm 0.03$ & $-0.60 \pm 0.03^{*}$ & $7.49 \pm 0.03$ & $-0.71 \pm 0.03^{*}$ \\
\hline 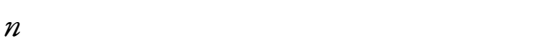 & 1,155 & & 936 & \\
\hline$\geq 5$ years $($ mean $=9.7 / 9.8)$ & $7.88 \pm 0.03$ & $-0.69 \pm 0.03^{*}$ & $7.75 \pm 0.03$ & $-0.80 \pm 0.03^{*}$ \\
\hline \multicolumn{5}{|l|}{ BL duration of metformin use } \\
\hline$n$ & 709 & & 580 & \\
\hline 0 to $<1$ year $($ mean $=0.6 / 0.6)$ & $7.70 \pm 0.04$ & $-0.63 \pm 0.03^{*}$ & $7.53 \pm 0.04$ & $-0.75 \pm 0.04^{*}$ \\
\hline$n$ & 1,274 & & 1,022 & \\
\hline$\geq 1$ to $<5$ years $($ mean $=2.6 / 2.6)$ & $7.70 \pm 0.03$ & $-0.63 \pm 0.02^{*}$ & $7.58 \pm 0.03$ & $-0.74 \pm 0.03^{*}$ \\
\hline$n$ & 468 & & 361 & \\
\hline$\geq 5$ years $($ mean $=7.9 / 7.7)$ & $7.93 \pm 0.05$ & $-0.70 \pm 0.04^{*}$ & $7.76 \pm 0.05$ & $-0.82 \pm 0.05^{*}$ \\
\hline
\end{tabular}

Data are mean $\pm S E$

b.i.d. twice daily, $B L$ baseline, BMI body mass index, $H b A_{1 c}$ hemoglobin $\mathrm{A}_{1 \mathrm{c}}$, Mean $\Delta$ mean change from $\mathrm{BL}, n$ number of patients with observations at both baseline and endpoint, $S U$ sulfonylurea, T2DM type 2 diabetes mellitus, Vilda vildagliptin

${ }^{*} P<0.0001$

The impact of disease progression on the efficacy of vildagliptin was evaluated by stratification according to three T2DM duration categories, $\quad 0$ to $<1$ year $\quad($ mean $=0.6$ years $)$, $\geq 1$ to $<5$ years (mean $=2.9$ years), and $\geq 5$ years (mean $=9.7$ years). In addition, the duration of 
metformin use was considered, with categories of 0 to $<1$ year (mean $=0.6$ years), $\geq 1$ to $<5$ years (mean $=2.6$ years), and $\geq 5$ years $\quad$ (mean $=$ 7.9 years). Patients with shorter and longer duration of T2DM and metformin use had very similar decreases in $\mathrm{HbA}_{1 \mathrm{c}}$. For example, $\mathrm{HbA}_{1 \mathrm{c}}$ ( \pm SE) was reduced by $-0.64 \pm 0.05 \%$ (baseline $7.47 \pm 0.06 \%$ ),$-0.60 \pm 0.03 \%$ (baseline $7.65 \pm$ $0.03 \%$ ), and $-0.69 \pm 0.03 \%$ (baseline $7.88 \pm$ $0.03 \%$ ) in the $\mathrm{T} 2 \mathrm{DM}$ duration subgroups of 0 to $<1, \geq 1$ to $<5$, and $\geq 5$ years, respectively.

Table 2 also displays efficacy results in the different sub-categories for the $\mathrm{SU}$ reference group. The results in patients receiving a SU were comparable to those seen in the vildagliptin group, with similar $\mathrm{HbA}_{1 \mathrm{c}}$ reductions across the different Homa IR, BMI, T2DM duration, and duration of metformin use subgroups.

\section{DISCUSSION}

The present paper evaluated the impact of IR, BMI, disease duration, and duration of metformin use on the efficacy of vildagliptin in patients with T2DM treated with metformin. The pooled analysis found similar efficacy of vildagliptin independent of these factors, indicating that patients with higher IR, more obese patients, and patients with long-standing T2DM can benefit from treatment with the DPP-4 inhibitor, vildagliptin, in combination with metformin.

These data can provide relevant information for the use of vildagliptin in clinical practice, in particular given the not uncommon perception that treatment with DPP-4 inhibitors may be less beneficial with increasing disease progression, due to loss of beta-cell function, and with increasing IR, where beta-cell function is proportionally less important. The notion of
DPP-4 inhibitors being more beneficial in patients with shorter disease duration may at least be in part related to the promise from animal models $[5,6]$ that these incretin-based therapies may be able to interfere with disease progression if used as an early intervention, when sufficient beta-cell function/mass can be still be preserved or restored, which raised particular attention when these drugs initially became available. On the other hand, consistent with the findings of the present report, vildagliptin has meanwhile been shown to be efficacious across a wide disease spectrum, including add-on therapy to insulin as well as patients with renal impairment, both involving patients with long-standing T2DM (mean T2DM duration 13-17 years) [20-23].

In this context, it is important to keep in mind that vildagliptin, in addition to improving beta-cell function, also enhances alpha-cell function (i.e., suppresses inappropriate glucagon secretion as shown after oral glucose and meal ingestion [24-26]), with the changes in islet hormone (i.e., increased insulin and reduced glucagon) secretion leading to a profound effect to suppress hepatic glucose production [27]. Furthermore, vildagliptin is associated with reduced insulin resistance due to reduced lipotoxicity $[28,29]$. Thus, a variety of pancreatic and extra-pancreatic effects are active to support the efficacy of vildagliptin [4].

Similar results to those seen with vildagliptin plus metformin were also seen in the group of patients treated with SUs in combination with metformin, who were analyzed as a reference group. The common perception is that both DPP-4 inhibitors and SUs tend to be more efficacious in lean than obese individuals and the reverse is true for TZDs. The data in this study do not support this perception about vildagliptin and SUs, and the authors are 
unaware of any data that does. In contrast, addition of the TZD, rosiglitazone, to metformin was indeed shown to be most efficacious in obese, insulin-resistant patients, as expected from the mechanism of action [30]. Similar results were also seen with pioglitazone added to SU therapy in a small Japanese study; $\mathrm{HbA}_{1 \mathrm{c}}$ was decreased considerably more in the Homa IR $\geq 4$ category compared to the $<4$ subgroup [31]. The current study does not address the question of whether a longer duration of SU use is associated with a reduced response, but indicates that addition of SUs to patients with a longer duration of T2DM is not associated with reduced efficacy. This is in contrast to one open-label study of glimepiride monotherapy [32], which showed a weak association of longer duration of diabetes with the likelihood of being a nonresponder (odds ratio $[\mathrm{OR}]=1.096)$; however, the study was confounded by a strong correlation with previous oral antidiabetic drug (OAD) treatment $(\mathrm{OR}=2.506)$.

In light of the applicability of the reported results, it is important to note that each of the categories investigated included a broad range of vildagliptin-treated patients, with means of IR categories from 2.8 to 8.6 , of BMI from 24.9 to $35.3 \mathrm{~kg} / \mathrm{m}^{2}$, and of disease duration from $<1$ year to nearly 10 years (overall range 0.1-40.1 years). Another important factor for the interpretation of the subgroup results is that $\mathrm{HbA}_{1 \mathrm{c}}$ levels were well matched between the different categories, which is an important consideration given that $\mathrm{HbA}_{1 \mathrm{c}}$ levels strongly influence response to treatment. Since metformin was used as a background drug, some limitations of the clinical applicability of the present results to other indications cannot be ruled out, and it will be of interest to investigate whether similar results will be seen with vildagliptin in combination with other drugs, as well as in monotherapy. While no such data are currently available for the subgroups of disease duration or IR stage, in a study with vildagliptin monotherapy in patients with mild hyperglycemia, the same treatment effect was seen in patients with baseline $\mathrm{BMI}<30$ and $\geq 30 \mathrm{~kg} / \mathrm{m}^{2}$ [33].

\section{CONCLUSION}

Taken together, the present pooled analysis provides a comprehensive assessment of the efficacy of vildagliptin in subgroups of IR stage and BMI, as well as disease duration and duration of prior metformin use, showing similar efficacy of vildagliptin across a wide spectrum of these categories.

\section{ACKNOWLEDGMENTS}

The authors acknowledge the patients, investigators, and staff at participating sites for all the studies. This work was funded by Novartis Pharmaceuticals Corporation. Dr. Schweizer is the guarantor for this article, and takes responsibility for the integrity of the work as a whole.

Conflict of interest. All authors are employees of Novartis.

Open Access. This article is distributed under the terms of the Creative Commons Attribution Noncommercial License which permits any noncommercial use, distribution, and reproduction in any medium, provided the original author(s) and source are credited. 


\section{APPENDIX}

Table 3 Vildagliptin add-on to metformin studies contributing to analyses

\begin{tabular}{|c|c|c|c|c|}
\hline Study No. & Study description & $\begin{array}{l}\text { Randomized } \\
\text { patients }\end{array}$ & $\begin{array}{l}\text { Treatment } \\
\text { duration } \\
\text { (weeks) }\end{array}$ & Publication \\
\hline 1 & $\begin{array}{l}\text { Placebo-controlled efficacy/safety study in T2DM patients } \\
\text { inadequately controlled with metformin }\left(\mathrm{HbA}_{1 \mathrm{c}} 7.5-11 \%\right)\end{array}$ & 544 & 24 & {$[15]$} \\
\hline 2 & $\begin{array}{l}\text { Active-controlled (glimepiride) long-term efficacy/safety study in } \\
\text { T2DM patients treated with metformin }\left(\mathrm{HbA}_{\mathrm{lc}}>6.5-8.5 \%\right)\end{array}$ & 3,118 & $\geq 104$ & {$[16,34]$} \\
\hline 3 & $\begin{array}{l}\text { Active-controlled (gliclazide) long-term efficacy/safety study in } \\
\text { T2DM patients inadequately controlled with metformin }\left(\mathrm{HbA}_{1 \mathrm{c}}\right. \\
7.5-11 \%)\end{array}$ & 1,007 & 52 & {$[17]$} \\
\hline 4 & $\begin{array}{l}\text { Active-controlled (pioglitazone) long-term efficacy/safety study in } \\
\text { T2DM patients inadequately controlled with metformin }\left(\mathrm{HbA}_{1 \mathrm{c}}\right. \\
7.5-11 \%)\end{array}$ & 576 & 52 & {$[18,35]$} \\
\hline
\end{tabular}

$H b A_{1 c}$ hemoglobin $\mathrm{A}_{1 c}, T 2 D M$ type 2 diabetes mellitus

\section{REFERENCES}

1. Mentlein R, Gallwitz B, Schmidt WE. Dipeptidylpeptidase IV hydrolyses gastric inhibitory polypeptide, glucagon-like peptide-1(7-36)amide, peptide histidine methionine and is responsible for their degradation in human serum. Eur J Biochem. 1993;214:829-35.

2. Creutzfeldt W. The incretin concept today. Diabetologia. 1979;16:75-85.

3. Creutzfeldt W, Nauck M. Gut hormones and diabetes mellitus. Diabetes Metab Rev. 1992;8:149-77.

4. Ahren B, Schweizer A, Dejager S, Villhauer EB, Dunning BE, Foley JE. Mechanisms of action of the dipeptidyl peptidase-4 inhibitor vildagliptin in humans. Diabetes Obes Metab. 2011;13:775-83.

5. Perfetti R, Hui H. The role of GLP-1 in the life and death of pancreatic beta cells. Horm Metab Res. 2004;36:804-10.

6. Duttaroy A, Voelker F, Merriam K, et al. The DPP-4 inhibitor vildagliptin increases pancreatic beta cell mass in neonatal rats. Eur J Pharmacol. 2011;650:703-7.

7. Dhillon S, Weber J. Saxagliptin. Drugs. 2009;69:2103-14.

8. Keating GM. Vildagliptin-a review of its use in type 2 diabetes mellitus. Drugs. 2010;70:2089-112.
9. Dhillon S. Sitagliptin: a review of its use in the management of type 2 diabetes mellitus. Drugs. 2010;70:489-512.

10. Scott LJ. Linagliptin: in type 2 diabetes mellitus. Drugs. 2011;71:611-24.

11. Ligueros-Saylan M, Foley JE, Schweizer A, Couturier A, Kothny W. An assessment of adverse effects of vildagliptin versus comparators on the liver, the pancreas, the immune system, the skin and in patients with impaired renal function from a large pooled database of Phase II and III clinical trials. Diabetes Obes Metab. 2010;12:495-509.

12. Schweizer A, Dejager S, Foley JE, Kothny W. Assessing the general safety and tolerability of vildagliptin: value of pooled analyses from a large safety database versus evaluation of individual studies. Vasc Health Risk Manag. 2011;7:49-57.

13. Schweizer A, Dejager S, Foley JE, Couturier A, LiguerosSaylan M, Kothny W. Assessing the cardiocerebrovascular safety of vildagliptin: meta-analysis of adjudicated events from a large Phase III type 2 diabetes population. Diabetes Obes Metab. 2010;12:485-94.

14. Schweizer A, Dejager S, Foley JE, Shao Q, Kothny W. Clinical experience with vildagliptin in the management of type 2 diabetes in a patient population $\geq 75$ years: a pooled analysis from a database of clinical trials. Diabetes Obes Metab. 2011;13:55-64.

15. Bosi E, Camisasca RP, Collober C, Rochotte E, Garber AJ. Effects of vildagliptin on glucose 
control over 24 weeks in patients with type 2 diabetes inadequately controlled with metformin. Diabetes Care. 2007;30:890-5.

16. Ferrannini E, Fonseca V, Zinman B, et al. Fifty-twoweek efficacy and safety of vildagliptin versus glimepiride in patients with type 2 diabetes mellitus inadequately controlled on metformin monotherapy. Diabetes Obes Metab. 2009;11:157-66.

17. Filozof C, Gautier J-F. A comparison of efficacy and safety of vildagliptin and gliclazide in combination with metformin in patients with type 2 diabetes inadequately controlled with metformin alone: a 52-week, randomized study. Diabet Med. 2010;27:318-26.

18. Bolli G, Dotta F, Rochotte E, Cohen SE. Efficacy and tolerability of vildagliptin versus pioglitazone when added to metformin: a 24-week, randomized, doubleblind study. Diabetes Obes Metab. 2008;10:82-90.

19. Rigalleau V, Lasseur C, Perlemoine C, et al. Estimation of glomerular filtration rate in diabetic subjects. Cockcroft formula or modification of diet in renal disease study equation? Diabetes Care. $2005 ; 28: 838-43$.

20. Fonseca V, Schweizer A, Albrecht D, Baron MA, Chang I, Dejager S. Addition of vildagliptin to insulin improves glycemic control in type 2 diabetes. Diabetologia. 2007;50:1148-55.

21. Lukashevich V, Kozlovski P, Foley J, Kothny W. Vildagliptin combined with insulin reduces HbA1c without increasing risk of hypoglycemia and weight gain in patients with type 2 diabetes mellitus. Poster to be presented at: The 72nd Scientific Sessions of the American Diabetes Association; June 8-12, 2012; Philadelphia, PA, USA.

22. Lukashevich V, Schweizer A, Shao Q, Groop P-H, Kothny W. Safety and efficacy of vildagliptin versus placebo in patients with type 2 diabetes and moderate or severe renal impairment: a prospective 24-week randomized placebocontrolled trial. Diabetes Obes Metab. 2011;13:947-54.

23. Dejager $S$, Schweizer A. Incretin therapies in the management of patients with type 2 diabetes mellitus and renal impairment. Hosp Pract (Minneap). 2012;40:7-21.

24. He YL, Serra D, Wang Y, et al. Pharmacokinetics and pharmacodynamics of vildagliptin in patients with type 2 diabetes mellitus. Clin Pharmacokinet. 2007;46:577-88.

25. Ahren B, Landin-Olsson M, Jansson P-A, Svensson $\mathrm{M}$, Holmes D, Schweizer A. Inhibition of dipeptidylpeptidase-4 reduces glycemia, sustains insulin levels and reduces glucagon levels in type 2 diabetes. J Clin Endocrinol Metab. 2004;89:2078-84.

26. Hare KJ, Vilsboll T, Asmar M, Deacon CF, Knop FK, Holst JJ. The glucagonostatic and insulinotropic effects of glucagon-like peptide 1 contribute equally to its glucose-lowering action. Diabetes. 2010;59:1765-70.

27. Balas B, Baig MR, Watson $\mathrm{C}$, et al. The dipeptidylpeptidase-4 inhibitor vildagliptin suppresses endogenous glucose production and enhances islet function after single-dose administration in type 2 diabetic patients. J Clin Endocrinol Metab. 2007;92:1249-55.

28. Azuma K, Radikova Z, Mancino J, et al. Measurements of islet function and glucose metabolism with the dipeptidyl peptidase 4 inhibitor vildagliptin in patients with type 2 diabetes. J Clin Endocrinol Metab. 2008;93:459-64.

29. Boschmann M, Engeli S, Dobberstein K, et al. Dipeptidyl-peptidase-IV inhibition augments postprandial lipid mobilization and oxidation in type 2 diabetic patients. J Clin Endocrinol Metab. 2009;94:846-52.

30. Jones TA, Sautter M, van Gaal LF, Jones NP. Addition of rosiglitazone to metformin is most effective in obese, insulin-resistant patients with type 2 diabetes. Diabetes Obes Metab. 2003;5:163-70.

31. Nagasaka S, Aiso Y, Yoshizawa K, Ishibashi S. Comparison of pioglitazone and metformin efficacy using homeostasis model assessment. Diabet Med. 2004;21:136-41.

32. Charpentier G, Vaur L, Halimi S, et al. Predictors of response to glimepiride in patients with type 2 diabetes mellitus. Diabetes Metab. 2001;27:563-71.

33. Scherbaum WA, Schweizer A, Mari A, et al. Efficacy and tolerability of vildagliptin in drug-naïve patients with type 2 diabetes and mild hyperglycemia. Diabetes Obes Metab. 2008;10:675-82.

34. Matthews DR, Dejager S, Ahren B, et al. Vildagliptin add-on to metformin produces similar efficacy and reduced hypoglycaemic risk compared with glimepiride, with no weight gain: results from a 2-year study. Diabetes Obes Metab. 2010;12:780-9.

35. Bolli G, Dotta F, Colin L, Minic B, Goodman M. Comparison of vildagliptin and pioglitazone in patients with type 2 diabetes inadequately controlled with metformin. Diabetes Obes Metab. 2009;11:589-95. 